\title{
Defining criteria and indicators for a sustainability label of local public services
}

\author{
Ana Rita Domingues ${ }^{a, *}$, Sara Moreno Pires ${ }^{b}$, Sandra Caeiro ${ }^{a, c}$, Tomás B. Ramos $^{a}$ \\ a CENSE, Center for Environmental and Sustainability Research, Departamento de Ciências e Engenharia do Ambiente, Faculdade de Ciências e Tecnologia, \\ Universidade Nova de Lisboa, Campus da Caparica, 2829-516 Caparica, Portugal \\ ${ }^{\mathrm{b}}$ UCILeR, University of Coimbra, Institute for Legal Research, Pátio da Universidade, 3004-545 Coimbra, Portugal \\ c Departamento de Ciências e Tecnologia, Universidade Aberta, R. Escola Politécnica, $n^{\circ}$ 141, 1269-001 Lisboa, Portugal
}

\section{A R T I C L E I N F O}

\section{Article history:}

Received 18 September 2014

Received in revised form 31 March 2015

Accepted 6 May 2015

\section{Keywords:}

Sustainability label

European Union Ecolabel

Global Reporting Initiative

Indicators

Public service

Communication

\begin{abstract}
A B S T R A C T
The assessment of sustainability of public services is an important issue, especially at local level, taken into account the central role of local governments as a major public employer and provider of a diversity of services. Local governments are close to citizens and are moving faster than other public sector levels with regard to the integration of sustainability principles in their operations and strategies. A sustainability label to communicate public service performance enables to disclose information directly to service users. However, there is a dearth of research about labels addressing specific sustainability criteria for local services. The main aim of this research was the development of a conceptual framework to define a sustainability label, as a tool to assess and communicate sustainability of local public services. The approach was developed taking into account criteria of the European Union Ecolabel and indicators of the Global Reporting Initiative guidelines. The ecolabel is a relatively well-known voluntary instrument in Europe and has the potential for application in public service activities and operations, but only assess the environmental component of sustainability. The Global Reporting Initiative, in particular the Sector Supplement for Public Agencies, was then used to integrate the other sustainability components. Thirtysix (36) criteria and respective indicators were adapted for the proposed sustainability label conceptual framework. A Portuguese local public service was used as an exploratory case study to test the proposed conceptual model into practice. The overall results demonstrate that few criteria were accomplished in this local public service, stressing that new practices and public policies need to be adopted to invert the current trend, especially through the application of assessment systems. This exploratory case study research has shown how useful can be a sustainability label to support local governments in evaluating and communicating the sustainability performance of their public services. This case could drive and support other government levels, including central and regional public administration, in adopting and exploring public service labels and their associated performance approaches.
\end{abstract}

(c) 2015 Elsevier Ltd. All rights reserved.

\section{Introduction}

Environmental labels act as market regulators, when applied by third parties, to prevent the advertisement of any product (goods and services) as green when it does not comply with strict environmental standards (Dosi and Moretto, 2001). In a society where consumption patterns are one of the major driving forces behind environmental degradation, environmental labelling schemes emerge as an environmental policy instrument with a

\footnotetext{
* Corresponding author. Tel.: +351 212948397; fax: +351 212948554

E-mail address: arsd@fct.unl.pt (A.R. Domingues).
}

large potential to contribute to an effective reduction of environmental impacts associated to economic activities (Santos et al., 2006). These labels result from criteria that take into account the environmental impacts that products may have in their life-cycle to make sure that the label gives consumers/users the possibility to choose the products that are least harmful to the environment (Lavallée and Plouffe, 2004). They are a way to narrow the information gap, where independent third parties assure consumers/users that the product meets those environmental standards (van Amstel et al., 2008). Therefore, they can motivate consumers/users to switch to less environmentally harmful and resource-consuming products (Thøgersen, 2002), with simple, useful and credible information about complex issues along the supply chain (Hartlieb and 
Jones, 2009; Ibanez and Grolleau, 2008). Flexible and market sensible self-regulatory information instruments, such as ecolabels have been increasingly adopted and recognised worldwide as an alternative to governmental command and control regimes towards environmental management, as discussed by Bratt et al. (2011).

Environmental labels, often named as ecolabels, are supported by procedures and criteria that are usually defined in standards or regulations. The International Standards from the 14020 series (ISO, 2006, 2000, 1999a,b), which encompasses aspects related to environmental labels and declarations or the European Union (EU) ecolabel (EC, 2010) are examples of broad international initiatives in this field. This EU label, launched in 1992, is well established and promotes products with less environmental impacts than their similar, ensured by meeting the label's environmental performance criteria throughout the product life-cycle. Currently, the EU ecolabel mainly covers goods (e.g. paints and varnishes, cleaners, textile products, paper, televisions) and only two product groups related to services: tourist accommodation and campsites (EC, 2009a,b). Criteria of the EU ecolabel for services are intangible as they cannot be stocked and easily be demonstrated. Services can be sold but there is not necessarily any transfer of ownership. It is one of the most well-known ecolabels in Europe and it is usually considered as a credible and reliable performance assessment and communication tool (ICLEI European Secretariat et al., 2012).

The work conducted by UNOPS (2009), stresses that only independent and reliable labels that consider the life-cycle impact of products are called ecolabels, to avoid misconceptions commonly found in the booming green market. Currently, and according to the Ecolabel Index (Big Room, 2014), a global directory of ecolabels, there are about 458 different ecolabels in 197 countries covering 25 different industry sectors. In addition, the concept of ecolabels can be enlarged to the one of sustainability labels, aiming the assessment and communication of sustainability performance of goods or services, integrating in a holistic way different dimensions of sustainability (economic, social and the environment). However, despite some literature regarding sustainability labels, there has been a misuse of the term sustainability in labels that do not encompass the main sustainability dimensions but rather just one of them (mainly the environment). In fact, some labels have "sustainability" or "sustainable" in their name, but overall they encompass mostly environmental and social aspects. ${ }^{1}$ Nevertheless, other examples like the Sustainable Winegrowing New Zealand (New Zealand Wine, 2014) have criteria from different dimensions of sustainability, although most of them are environment related. Similarly, the scientific literature, shows different works that have investigated environmental or sustainability related labels, for example the consumer's attitudes to sustainability labels on meat using only three criteria related to organic meat, free range, animal welfare and carbon footprint (van Loo et al., 2014), consumer preferences among fair trade, rain forest alliance and carbon footprint labels (Vecchio and Annunziata, 2015) or public perceptions regarding a sustainable forestry label (Hansmann et al., 2006). However, only few works, such as the one conducted by Hansmann et al. (2006), attempt to analyse the integrated sustainability dimensions.

Therefore, and despite the above-mentioned works and several research studies related with sustainability labels, there is a lack of research that explores an integrative analysis of product

\footnotetext{
1 Some example are the following: Florverde Sustainable Flowers, NSF Sustainability Certified Products (for carpet, resilient floor coverings, commercial furnishings fabric, wallcovering products), Sustainable Carpet Certification (based on NSF/ANSI 140 Certification Standard), Roundtable on Sustainable Biomaterials, Sustainable Forestry Initiative, Sustainable Green Printing Partnership, Sustainable Tourism Education Program (eco-certified sustainable travel), and Water Quality Association (WQA) Sustainability Mark (Big Room, 2014).
}

performance sustainability in different dimensions. Most labels, that claim to be sustainable; are in fact based on environmental criteria and to a lesser extent on social criteria as well. In addition, most of the labels address goods, so there is the need to further address service labels and not only goods. To achieve this integration, ecolabels could learn and be supported by other performance assessment and reporting tools, such as the Global Reporting Initiative (GRI) (GRI, 2013a), a common framework applicable and recognised internationally (Lamprinidi and Kubo, 2010; Farneti and Guthrie, 2009), where a set of indicators is proposed to assess and communicate (throughout a report) the sustainability performance of organisations.

It should be also noted that the majority of environmental related label initiatives were developed for goods and services that are produced by the private sector, as demonstrated by the products covered by the EU ecolabel (see EC, 2014) or by the overview provided by Ecolabel Index (Big Room, 2014). The lack of action on developing and investigating ecolabels for public sector service reflects a general dearth of research on integrative tools to assess and communicate the sustainability performance of public services, which is explored by Ramos et al. (2007) and Lundberg et al. (2009). Until now there are no sustainability labels for public services and sustainability performance measures for the public sector are poorly developed and implemented since this sector do not notice the need to be competitive (Adams et al., 2014). Indeed, the major focus has been to assess sustainability performance of private sector companies and their corporate reporting schemes (Enticott and Walker, 2008; Walker and Brammer, 2012; Williams et al., 2011). However, the public sector covers a significant number of human resources, provides various services and consumes many resources (GRI, 2005). Given its size and influence, and particularly at the local level, public agencies are expected to lead by example the achievement of sustainability goals, informing policy formulation, supporting planning and decision-making from sustainable development based standpoints (Williams et al., 2011). The integration of sustainable development principles and practices into government processes, including policy formulation and operations is crucial for the achievement of sustainable development since public sector represents an important part of international economic activities (Ball and Grubnic, 2007; Walker and Brammer, 2012).

Public services at local level are close to general public and users, so a label is a simple way to communicate the sustainability performance of the service to stakeholders. It has the same goal as a reporting scheme, to communicate the performance to stakeholders due to legitimacy and accountability motivations (Bebbington et al., 2009; Comyns et al., 2013; Farneti and Guthrie, 2009), whereas the label provides the information at the time that the user interacts with the service (Dosi and Moretto, 2001). According to Navarro Galera et al. (2014), who analysed the practices of sustainability disclosure in local governments in Anglo-Saxon and Nordic countries, the development level of a country and/or the governance quality is not inevitably related to the transparency of local governments regarding sustainability. Consequently, a sustainability label for local public services could not only enable the assessment of the sustainability performance of activities and operations of public organisations from countries regardless their characteristics (developing or developed countries), but it could also be used as a communication tool to stakeholders and entire worldwide society.

The main aim of this research was the development of a conceptual framework to define a sustainability label, as a tool to assess and communicate sustainability of local public services. This framework was based on a set of criteria and performance indicators adapted from the EU ecolabel criteria and the GRI indicators, which complement the lack of economic and social aspects in the EU ecolabel and constitutes the only reporting guidelines that 
have specific indicators for public agencies. Labelling and reporting schemes share at least one main common goal that is communication and providing information to stakeholders, despite using different mechanisms for social interaction. The proposed sustainability label was tested in the European context with a Portuguese local public service - the service of licensing and support to economic activities of the municipality of Oeiras. This service was used as an exploratory case study in order to assess the applicability and usefulness of the proposed approach.

\section{Sustainability labels, assessment and communication in local public services}

In general, services have a close proximity between buyer and seller, so it may be easier to assess impacts in services, where the originator has more control over the use of a service than over the use of a good and also usually production and consumption generally coincide (Welford et al., 1998). Being the public sector mostly a service's provider, the quality of a service reflects decision-making pressures and the maintenance or improvement of governance's credibility (Montesinos and Brusca, 2009). Sustainability labels can be used to provide relevant information on their general sustainability profile to different stakeholders, including national and regional authorities, local communities and citizens, non-governmental organisations, corporations, academia, and all institutions related with that service. A mandatory label such as the case of graded ecolabels (e.g. EU Energy label for household products) would motivate the improvement of service performance to achieve a good sustainability performance.

Public agencies are expected to be open and transparent in their management of public funds and assents in order to respond to the society requirements (GRI, 2005; Nogueiro and Ramos, 2014). Despite public organisations pursue political and social goals rather than activities that maximise profit (Boland and Fowler, 2000) or having commercial objectives, a sustainable public service could have a high productivity profile, showing efficiency and effectiveness in their activity. To accomplish these goals, organisations must have qualified internal stakeholders (e.g. employees) that could implement sustainability practices and also to enhance the development of others. Moreover, productivity and customers' satisfaction's criteria are essential to create an intrinsic value of the public service and to justify its existence (Jarrar and Schiuma, 2007). This is however a challenging task for public organisations due to the fact that the sector has disregarded, neglected and/or omitted assessments of their productivity and their own problems, namely the environmental ones and impacts for years (Ramos et al., 2007). Public organisations are usually unaware of the environmental impacts related to their services. Furthermore, in recent decades, the public sector in various developed countries has faced several other common pressures, such as centralised organisational structures, complex decision-making processes, increased competitiveness, budget constraints, cultural and social changes, increased expectations of society, fast technological changes, and the need for communication and survival (Mendes et al., 2012). According to the same authors, it has also faced unmotivated employees, devaluation of the concept of a public service mission, and a negative opinion of its services among the general population.

Nevertheless, there has been a growing need and interest to integrate sustainability informed strategies into the core business processes of the public sector (Brammer and Walker, 2011; Enticott and Walker, 2008). Several countries have started to implement initiatives related to sustainable practices, e.g. in the UK (DEFRA, 2007; Enticott and Walker, 2008), in Sweden (Lundberg et al., 2009), in the Netherlands (Hoppe and Coenen, 2011) or in the USA (Saha, 2009). These initiatives focus mainly on the environmental dimension of sustainable development and on the measurement and assessment of government operational performance, namely the assessment of government operations and management practices. It is also increasingly recognised that sustainability performance assessment is a tool that allows public organisations to assess the effectiveness of the integration of sustainability considerations into governmental processes (Lundberg et al., 2009; Nogueiro and Ramos, 2009). These authors also stress that in general, these efforts have not been accompanied by guidelines designed exclusively and specifically to public organisations, and local governments in particular, which may justify the slow development of sustainability performance assessment in the public sector.

However, regarding local public administration, municipalities have particularly been part of a wider sustainability culture change movement, as they are becoming widely recognised as sustainability leaders, advocating to other levels of government (Strengers, 2004). Local public agencies play a central role in adopting sustainable initiatives and this role needs to be strengthened, as discussed by Williams et al. (2011). For example in Norway, almost half of all governmental expenditures are from local government consumption (counties and municipal services), being responsible for the emission of $1 \mathrm{t} \mathrm{CO}_{2}$ eq/cap.year (Larsen and Hertwich, 2011). Also in Portugal, local authorities are frequently the main local employer and play a central role in local development, regardless of size, location, or demographic characteristics (Nogueiro and Ramos, 2009).

Some environmental performance standardised tools have been used for public services by local authorities, such as Environmental Management Systems (EMS - according to ISO 14001 or EMAS) (Montesinos and Brusca, 2009; Petrosillo et al., 2012). Although several well-known advantages of these tools, such as more distinct structure and better-defined liability, among the disadvantages of an EMS is the time consumption and the administrative work needed (Norén and Malmborg, 2004). These tools were mainly developed for private sector, so their usefulness to public sector is not clear because of the different characteristics of both sectors (Ball and Bebbington, 2008), including ownership, trading status, competition, accountability, heterogeneity, complexity and uncertainty.

Other standardised tools are closely linked to sustainability performance, such as the guidelines promoted by the GRI (GRI, 2013a). These guidelines are used to assess and communicate sustainability performance of an organisation, covering economic, environmental and social aspects. The GRI framework as well as other sustainability tools mentioned earlier use or propose indicators to assess the sustainability performance of an organisation. Sustainability indicators evaluate and communicate complex sustainability information, being considered important tools in decision-making (Waas et al., 2014). GRI has a sector supplement for public agencies that is one of few international guidelines specifically tailored for public sector sustainability performance assessment and reporting (GRI, 2005).

The extension of voluntary procedures to local authorities represents an additional step forward in the field of a pro-active sustainable management approach. One example is the proliferation of local initiatives to develop their own local sustainability indicators system (Moreno Pires, 2014). Sustainability indicators have been largely used as robust, less bureaucratic and more meaningful to citizens' to evaluate, compare and communicate sustainability performance of the public sector at local level. Examples of these indicators are being used worldwide, in Bristol, UK (McMahon, 2002), in Seatle, USA (Holden, 2006), in municipalities in Lebanon (Nader et al., 2008), in Jining, China (Li et al., 2009), in Padua, Italy (Scipioni et al., 2009), in several municipalities in Italy (Mazzi et al., 2012; Petrosillo et al., 2012) or in Palmela, Portugal (Moreno Pires and Fidélis, 2012). Nevertheless, 
the growing of contextual and isolated initiatives undermines the capacity to compare data, problems, policy options or to benchmark key indicators among cities and contexts. Standardisation is useful and critical for cities if standardised indicators are applied with flexibility, enabling the sharing of guidelines, ideas and experiences on sustainable development policies (Moreno Pires et al., 2014). Municipalities would benefit from building up and developing more sustainability capabilities (Michelsen and Boer, 2009; Nader et al., 2008). Nevertheless, at local level, most sustainability indicators focus on obvious outputs (e.g. recycling and air pollution) but not on other outcomes (e.g. biodiversity, social wellbeing) (Enticott and Walker, 2008; Hoppe and Coenen, 2011) or on outcomes outside local/service boundaries to capture external impacts (leakage effects) and dependencies of cities/services on other areas, particularly in terms of environmental aspects (Mori and Christodoulou, 2012). Measurements of social capital are also sparse despite efforts to develop indicators by government and voluntary organisations. For instance, equity has been neglected in empirical research of what communities are doing to promote local sustainability. In times of evidence-based policy, the lack of these indicators threatens not only future research into public sector sustainability performance, but also funding programmes for these areas of sustainability (Enticott and Walker, 2008).

The use of sustainability labels, based on indicators, on local public organisations embracing holistically environmental, economic and social dimensions of public services can provide directly available information to users, allowing them to know about the sustainable performance of those services. Local governments beneficiate with local partnerships or networks and network members interaction, using best-practices business executives and municipalities to become ambassadors and change agents, respectively, bringing corporate social responsibility and sustainability forward in corporations and guarantee sustainable development (Nielsen and Thomsen, 2011).

With increasing concern about sustainable development and sustainability reporting, it is now time for action if local government is to foster and pursue the sustainability labelling agenda, as leaders in the public sector (Williams et al., 2011).

\section{Methods}

\subsection{Sustainability label framework}

An approach to develop criteria and indicators for a sustainability label for public services is proposed, seeking to be applied to public services provided by local administration, including municipalities, local government agencies or departments. This sustainability label for public services integrates environment, social and economic domains and attempts to respond to a dearth of scientific and practical applications, which could convey sustainability information increasingly required by stakeholders. As stressed by CEEP (2009), citizens are looking for public services that take their social responsibility in an accountable manner and which can demonstrate their actions.

The main purpose of this label is to support public organisations with an operational and performance management instrument, to be used as a tool to assess and communicate the service sustainability performance. The approach is focused on the selection, definition, development and testing of criteria and indicators to conduct performance assessment and communication (Fig. 1). Criterion is assumed for this work as a target level, or yardstick against which sustainability performance is assessed. Indicators provide the operational measures (quantitative or qualitative) for each proposed criteria. Indicators are used in this approach as measures that convey "value added messages" in a simplified and useful manner to stakeholders, and that an indicator can be derived from a single variable to reflect some attribute or from an aggregation of several variables, as defined by Caeiro et al. (2012) and Ramos and Caeiro (2010).

The developed method assumed that some of the standardised and well establish EU ecolabel and GRI fundamentals, and their assessment tools, could be adapted to support the main components of a sustainability label for a local public service. The GRI sector supplement for public agencies (GRI, 2005) is used as a complement of the EU ecolabel, to integrate in a holistic way the social and economic domains of sustainability that ecolabel lacks. GRI is a reporting guideline but also a system that can provide the certification of the reporting process, using several indicators to assess and communicate the sustainability of organisations. These indicators are often used in a fragmentary way as stated by several authors (e.g. Farneti et al., 2011; Guthrie and Farneti, 2008), where organisations select the most appropriate set. The assessment made by the EU ecolabel result in a report. In the same way, depending on the application level requirements of the GRI there is also a "label" associated, represented by a reporting category (GRI, 2013b). Therefore, the proposed approach tailors the main components and features of those two initiatives in order to be applicable to the public sector.

This method assumed that a sustainability label and their assessment criteria and indicators should be centred on the entire public service, by integrating the different sustainability dimensions, which ultimately define whether the service is sustainable. Good conditions in one domain (e.g. production of urban solid waste) could not have a positive correlation with the performance for other domains (e.g. health and safety at work).

The proposed approach follows three main stages:

\section{(a) Local public service profile: main characteristics and features}

A first step was the identification and characterisation of the main common aims and scope of local public services and respective missions and activities (at operational and strategic levels). This information allows tracing the main inputs (resources required to provide a service, including human, financial and natural resources; buildings, equipment and consumables; policies and legislation; transportation options), processes (the way which a service is delivered), outputs (the service itself, specifically activities related to the service) and outcomes (impact of the service - healthier or more knowledgeable individuals, a safer society, among others) of a local public service (Carter et al., 1992). In addition, it was taken into account a clear description of the material (e.g. type of facilities and buildings, land area owned, employees, materials and equipment used) and non-material (e.g. delivering an electronic service) components and flows. Mainly direct aspects were taken into account as this research constitutes a first approach for the assessment of sustainability aspects of local public services.

After accomplished this initial review it was possible to assess the potential and most significant common environmental, economic and social aspects and impacts related with the activities originated by a local public service. These aspects refer to specific sustainability pressures such as water, materials and energy consumption, job insecurity factors, pollutant emissions, unequal conditions in the workplace, waste disposal or land use patterns produced by the organisation to deliver the service. The sustainability impacts demand organisation responses through the adoption and implementation of practices, tools and policies for sustainability performance improvement.

(b) Criteria and indicator selection/development for local public services 

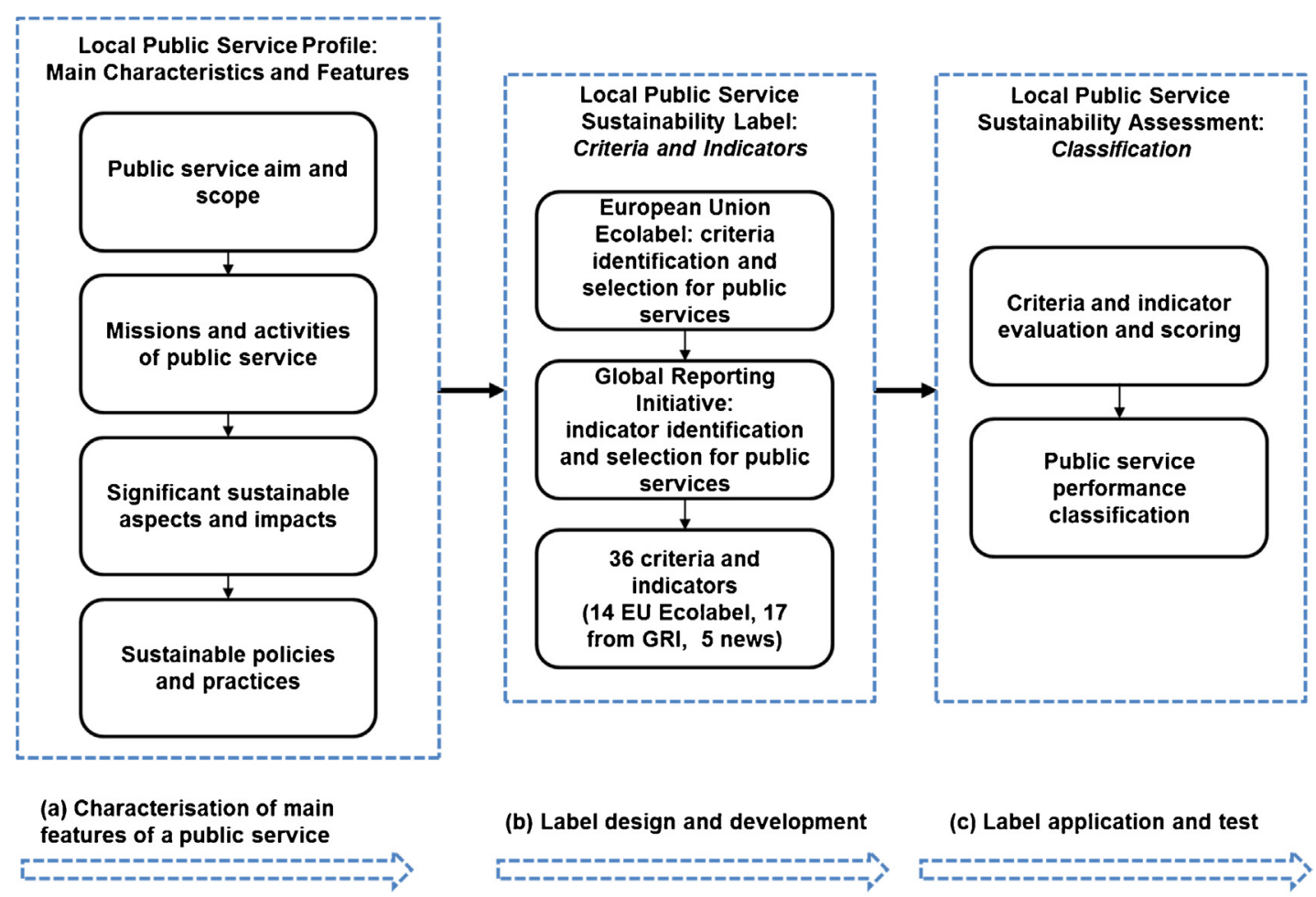

(b) Label design and development

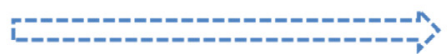

(c) Label application and test

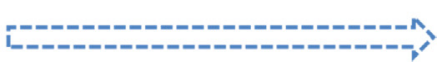

Fig. 1. Main steps for the design and development of the sustainability label for local public services.

The EU ecolabel criteria (mainly considering the services criteria - ecolabel for tourist accommodation service and for campsite service (EC, 2009a, 2009b) and the guidelines and indicators used by the Sector Supplement for Public Agencies of the Global Reporting Initiative (GRI, 2005) were used and adapted for the local public sector context. The only existent criteria in the EU ecolabel specific for services (tourist accommodation and campsites) were used because they have more similar characteristics, different from goods, when compared to public services, namely (Normann, 2001): (i) they are immaterial; (ii) ownership is not generally transferred; (iii) they cannot be resold; (iv) they cannot usually be effectively demonstrated; (v) they cannot be stored; (vi) production and consumption generally coincide and the selling is often spatially united; (vii) they cannot be transported; (viii) the user takes part directly in the production; (ix) in most cases direct contact is necessary; and (x) they cannot normally be exported, but the service delivery system can.

Although a label or a report can constitute similar approaches for sustainability communication they differ in the way information is presented. On one hand, a label allows presenting the performance assessment results when the consumer/user interacts with the good or the service. On the other hand, in a reporting scheme, the information is probably not available when the consumer/user interacts with the good or service, whereas the consumer/user can obtain the performance assessment results in a different moment. The preference for a ready to visualise, understand and significant impact tool lead to the development of the proposed sustainability label. Nevertheless, it is important that information is not lost for consumers/users and so it is critical that the criteria and indicators of that label are made publically available in the organisation for consultation.

A selection of the most relevant criteria and indicators for public services performance assessment and communication purposes was then carried out. These two initiatives do not deal with all local public sector specific features, which justify the inclusion of new criteria and indicators. The selection process took into account the previous analysis described in (a) - typical objectives, characteristics and resources that are common issues to public organisations activity and related sustainability significant issues. Criteria and indicators were selected according to their relevance and feasibility, following a similar approach than the one proposed by Ramos et al. (2007), Donnelly et al. (2007) and Niemeijer and Groot (2008). Due to the significant differences at organisational and functional levels, between public and private organisations, several assumptions and features were readjusted and reworked.

A total of 36 criteria were obtained, where 14 were selected, adapted or reworked from the EU ecolabel criteria, 17 from the GRI indicator set, and 5 criteria and respective indicators were developed and adopted as new ones to fulfil additional public sector specific properties. Those 5 indicators were added from the literature review at local scale (e.g. Li et al., 2009; Mascarenhas et al., 2010; Mazzi et al., 2012; McMahon, 2002; Nader et al., 2008; Petrosillo et al., 2012; Scipioni et al., 2009; Tanguay et al., 2010; USEPA, 1999), related with important specific impacts associated with public local level, not covered by GRI or ecolabel. Those indicators are emission of acidifying and eutrophying substances, labour productivity, indoor noise level, employee's residence and stakeholder communication. Also, since the EU ecolabel do not have explicit indicators but only criteria, and GRI only indicators, new indicators and criteria were developed, respectively, based upon the above mentioned works on indicator initiatives at local scale.

Table 1 presents the adopted criteria and respective performance indicators, covering several thematic areas within the main sustainability dimensions. Some indicators cover more than one thematic area, known as inter-linkage indicators as discusses by Lozano and Huisingh (2011).

Since public services are inserted in wider institutional contexts (municipalities or other local agencies), some indicators are assessed at organisational (municipal) level.

(c) Local public service sustainability assessment 
Table 1

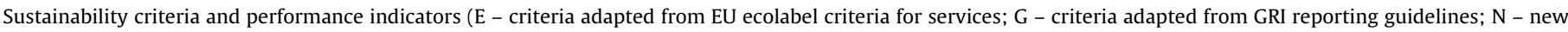
criteria included to reflect the sector characteristics).

Criteria and sustainability practices

Indicators (measurement unit)

Environmental protection and management (EN)

Biodiversity

Water and effluents

E

Climate change and

energy
EN1. Lack of activities and operations on protected and sensitive areas.

EN2. The service should not change the natural habitats due to its activities and operations, unless they lead to improvements in the environment for species that occupy those habitats.

EN3. Existence of a coordinated framework for environmenta issues, consisting of measures on activities related to the service to protect and conserve the ecosystems and minimise the environmental impacts associated with them.

EN4. Absence of habitats of species of the IUCN Red List affected by the activities and operations related to the service.

EN5. The average water flow of the taps shall not exceed 91/min. EN6. The water used in the activities and operations related to the service should not show a relationship with the degradation of ecosystems of which is captured.

EN7. Water consumption for the service is less than or equal to the average consumption in the region where the service is inserted. EN8. All toilets shall be fitted with either automatic (timed) or manual flushing systems so that there is no continuous flushing. EN9. The building where the service is available must have measures of water reuse, including the use of rainwater for toilet flushing and irrigation of outdoor areas if there are any.

EN10. Disinfectants shall be used only where they are necessary in order to comply with legal hygiene requirements and must have environmental certifications.

EN11. The greenhouse gas emissions must be less than the average emissions of the region. In the presence of vehicles assigned to the service, it must be of adequate number and with a highly efficiency, hybrid or having environmental certificates. The existence of alternative transport should be preferentially used. EN12. The service must have measures to use renewable energy sources and to improve their energy efficiency.

G
EN13. The energy consumption for the service should be below the average consumption in the region where the service is available. EN14. At least $50 \%$ of the electricity used for all purposes to the service shall come from renewable energy sources (wind, solar, geothermal wave, tidal, hydro power, biomass, landfill gas, sewage treatment plant gas and biogases).

EN15. No heavy oils having a sulphur content higher than $0.1 \%$ and no coal shall be used as an energy source (this criterion only applies to public service's buildings that have an independent heating system).

EN16. Existing a heat generating capacity it shall be a high efficiency cogeneration unit as defined by Article 3 and Annex III of Directive 2004/8/EC of the European Parliament and of the Council.

EN17. Automatic off-switch for the heating, air conditioning and light(s) when windows are open or people leave the room. If not, there shall be easily available information reminding to close the window(s) if the heating or air conditioning is on and turn off the light(s) when leaving the room.

EN18. All electric instruments and light bulbs shall have at least Class A energy efficiency or environmental labelling.

EN19. The windows in heated and/or air conditioned rooms and common areas shall have appropriate degree of thermal insulation according to the local regulations and climatic conditions and shall provide an appropriate degree of acoustic insulation. EN20. Maintenance and servicing of boilers and air conditioning systems shall be carried out at least yearly, or more often if so required by law or needed, by appropriately qualified professionals, following international or national standards, or according to the manufacturer's instructions.

EN21. Activities related to the service cannot lead to an increase of acidifying and eutrophying substances in the environment.
EN1. Activities and operations in protected or sensitive areas (No.) EN2. Changes to natural habitats resulting from activities and operations of the service (\%; ha) EN3. Measures implemented for the recovery of degraded areas caused by the service (No./type of measure)

EN4. IUCN Red List species with habitats in areas affected by activities and operations of the service (No.)

EN5. Water flow debit (1/min) EN6. Water sources and related ecosystems/habitats significant affected by water collection, and discharges of water and runoff (No.)

EN7. Total water use (litters/year)

EN8. Toilet flushing systems (\%)

EN9. Total recycling and reuse of water (\%; litters/year)

EN10. Detergents and disinfectants with environmental certifications (\%)

EN11. Greenhouse gas emissions (kg pollutant/year)

EN12. Initiatives to use renewable energy sources and to increase energy efficiency (No./year)

EN13. Final energy consumption by the service (Joules)

EN14. Consumption of electricity produced from renewable energy sources (\%)

EN15. Micro-production systems (type of energy sources and characteristics)

EN16. Efficiency of the equipment for the production of thermal energy (\%).

EN17. Switching off for the heating, air conditioning and light(s) (yes, no)

EN18. Equipment with environmental labelling or energy certificates (No.; \%)

EN19. Window insulation (U-value)

EN20. Maintenance of boilers and air conditioning systems (No./year)

EN21. Emission of acidifying and eutrophying substances ( $\mathrm{g} \mathrm{SO}_{2}$ and $\mathrm{PO}_{4} /$ year) 
Table 1 (Continued)

\begin{tabular}{|c|c|c|c|}
\hline & & Criteria and sustainability practices & Indicators (measurement unit) \\
\hline \multirow[t]{3}{*}{$\begin{array}{l}\text { Natural resources } \\
\text { management }\end{array}$} & G & $\begin{array}{l}\text { EN22. The service should promote the gradual reduction of urban } \\
\text { solid waste produced. }\end{array}$ & $\begin{array}{l}\text { EN22. Total amount of urban solid } \\
\text { waste produced by type and } \\
\text { destination ( } t / \text { year) }\end{array}$ \\
\hline & $\mathrm{E}$ & $\begin{array}{l}\text { EN23. Waste shall be separated into the categories that can be } \\
\text { handled separately by the local or national waste management } \\
\text { facilities. Unless required by law, not refillable and not reusable } \\
\text { products shall not be used. The disposable products shall only be } \\
\text { used if they are made out of renewable raw materials and are } \\
\text { biodegradable and compostable according to EN } 13432 \text {. }\end{array}$ & $\begin{array}{l}\text { EN23. Recycling and recovery of } \\
\text { waste (\%) }\end{array}$ \\
\hline & $\mathrm{E}$ & $\begin{array}{l}\text { EN24. The public service shall have procedures for collecting and } \\
\text { monitoring data on electricity and other energy sources and water } \\
\text { consumption. }\end{array}$ & $\begin{array}{l}\text { EN24. Procedures and practices for } \\
\text { water and energy monitoring } \\
\text { (yes/no) }\end{array}$ \\
\hline \multicolumn{4}{|l|}{ Economic aspects (EC) } \\
\hline \multirow[t]{3}{*}{ Economic development } & $\mathrm{N}$ & $\begin{array}{l}\text { EC25. The labour productivity should be equal or higher than the } \\
\text { national value. }\end{array}$ & $\begin{array}{l}\text { EC25. Labour productivity (average } \\
\text { percentage of objectives fulfilled } \\
\text { by employees of the public service) }\end{array}$ \\
\hline & G & $\begin{array}{l}\text { EC26. The service should include ethical criteria in the practice of } \\
\text { purchasing products from internal and external consumption. At } \\
\text { least half of the products purchased by the organisation must be } \\
\text { registered with social and environmental labels and/or by } \\
\text { certification's programme. }\end{array}$ & $\begin{array}{l}\text { EC26. Green Public Procurement } \\
\text { (\%; No.) }\end{array}$ \\
\hline & G & $\begin{array}{l}\text { EC27. Integration of non-core business expenditures in the } \\
\text { service's responsibility for their employees. }\end{array}$ & $\begin{array}{l}\text { EC27. Total spent on non-core } \\
\text { business infrastructure } \\
\text { development }(\%)\end{array}$ \\
\hline \multirow[t]{2}{*}{ Financial performance } & G & $\begin{array}{l}\text { EC28. The accounts relative to the public service must be } \\
\text { controlled, without increasing costs. These should be increased } \\
\text { only if the normal operation of the service is at risk. }\end{array}$ & EC28. Public expenditure $(€)$ \\
\hline & G & $\begin{array}{l}\text { EC29. Integration of sustainability issues on public financial } \\
\text { compromises. }\end{array}$ & $\begin{array}{l}\text { EC29. Integration of sustainability } \\
\text { criteria in public financial } \\
\text { compromises (\%; No.) }\end{array}$ \\
\hline \multicolumn{4}{|c|}{ Ethic and social responsibility (ET) } \\
\hline \multirow[t]{3}{*}{$\begin{array}{l}\text { Labour practices and } \\
\text { decent work }\end{array}$} & $\mathrm{N}$ & $\begin{array}{l}\text { ET30. The noise levels where the public service is provided need to } \\
\text { comply with the minimum health and safety requirements } \\
\text { regarding the exposure of employees to the noise defined by the } \\
\text { Directive } 2003 / 10 / C E \text { of the European Parliament and of the } \\
\text { Council of } 6 \text { February. }\end{array}$ & ET30. Noise level (dB(A)) \\
\hline & $\mathrm{E}$ & $\begin{array}{l}\text { ET31. The service shall have an environmental policy and shall } \\
\text { draw up a simple environmental policy statement and a precise } \\
\text { action programme to ensure the application of the environmental } \\
\text { policy. This has to be available for consultation by the public. } \\
\text { Comments and feedback from users collected by means of a } \\
\text { questionnaire or check list shall be taken into account. }\end{array}$ & $\begin{array}{l}\text { ET31. Environmental management } \\
\text { and social responsibility policy } \\
\text { (yes/no) }\end{array}$ \\
\hline & G & $\begin{array}{l}\text { ET32. Public service has to promote the equality and merit } \\
\text { benefits' on employees. }\end{array}$ & $\begin{array}{l}\text { ET32. Employees' benefits beyond } \\
\text { those legally mandatory (yes/no) }\end{array}$ \\
\hline \multirow[t]{4}{*}{$\begin{array}{l}\text { Social and service } \\
\text { responsibility }\end{array}$} & $\mathrm{E}$ & $\begin{array}{l}\text { EC33. The public service shall provide information and training to } \\
\text { the staff to ensure the application of sustainable measures (e.g. to } \\
\text { raise awareness of a responsible behaviour on energy and water } \\
\text { saving, chemical substances and waste). }\end{array}$ & $\begin{array}{l}\text { EC33. Specific training on } \\
\text { sustainable development skills } \\
\text { (percentage of employees; No.) }\end{array}$ \\
\hline & $\mathrm{N}$ & $\begin{array}{l}\text { EC34. At least } 30 \% \text { of employees allocated to the service must be } \\
\text { resident in the county where the organisation is situated. This } \\
\text { criterion applies only to utilities that have a geographical area of } \\
\text { jurisdiction not exceeding the equivalent of a district. }\end{array}$ & $\begin{array}{l}\text { EC34. Employees' residence in the } \\
\text { county where the organisation is } \\
\text { situated (\%; No.) }\end{array}$ \\
\hline & $\mathrm{N}$ & $\begin{array}{l}\text { ET35. The service has to communicate its performance to } \\
\text { stakeholders. }\end{array}$ & $\begin{array}{l}\text { ET35 Stakeholder communication } \\
\text { (number and type of reports or } \\
\text { communications/year) }\end{array}$ \\
\hline & G & $\begin{array}{l}\text { ET36. The service has to promote the continuous improvement of } \\
\text { its activities and the user's satisfaction. }\end{array}$ & $\begin{array}{l}\text { ET36 User's satisfaction } \\
\text { (percentage of user's satisfied; } \\
\text { Total No. assessed) }\end{array}$ \\
\hline
\end{tabular}

The nomenclature "product group" is used in the EU ecolabel to assess each product regarding their characteristics. The criteria are specific to each product group to address the specific characteristics of each product type. Each product has to accomplish requirements to be considered to a specific product group. Similarly in this work it is proposed a new service group the "local public service" that corresponds to any public service that is provided by a local public authority such as municipalities and parishes.

The EU ecolabel for services has 29 mandatory and 60 optional criteria (EC, 2009a,b). The service has to score a minimum of 20 points of the optional criteria in order to qualify for award of the EU ecolabel, as well as the compliance with all mandatory criteria.
Each optional criterion has a different score. This method assumes that each criterion has a different importance. Also for a report be GRI-based, report makers should self-declare the level to which they have applied the GRI Reporting Framework via the "Application Levels" system (GRI, 2013b). The reporting criteria at each level reflect a measure of the extent of application or coverage of the GRI Reporting Framework (use of minimum number of performance indicators). A "plus" (+) is available at each level (e.g., C+, $\mathrm{B}+, \mathrm{A}+)$ if external assurance is used for the report. Based on the EU ecolabel score and GRI application level, a classification method for the sustainability label for local public services is proposed. It is assumed that indicators have all the same weight for the award 
of the sustainability label. The sustainability label application level will be awarded taking into account a measure of central tendency, the percentile. Percentiles are often used to analyse and classify indicators' data in different contexts (e.g. Bornmann et al., 2013; Steinemann, 2003).

In order to receive the sustainability label for local public service, a service shall fulfil all the following requirements (adapted from EC (2009a, 2009b) and GRI (2013b)):

- Fall within the new service group "local public service".

- Until the end of validity period or during the maintenance of the characteristics assessed.

- Comply with each complementary criteria (classified as compliance; no compliance; insufficient data and not applicable) in order to fall within one of the four categories of the label application level according to:

A. Green award of the sustainability label: More than 75\% (4th quartile) of the criteria complied - public service is embracing sustainability and demonstrates good signals of engagement and performance developments.

B. Yellow award of the sustainability label: More than $50 \%$ and less than $75 \%$ (3rd quartile) of the criteria complied - public service is embracing some relevant aspects of sustainability but needs further engagement and performance developments.

C. Orange award of the sustainability label: More than $25 \%$ and less than $50 \%$ (2nd quartile) of the criteria complied - public service is aware for sustainability but needs performance improvements and developments.

D. Red award of the sustainability label: Less than 25\% (1st quartile) of the criteria complied - public service is way from sustainability and need major performance improvements and developments.

Each criterion and respective indicator can then be evaluated. Following a conservative principle, for each criterion without available data or information, is assumed as non-compliance. If the service fills the requirements corresponding to category A (green label), it is awarded with the green sustainability label and presents the following performance outcome: this public service meets the requirements for a good integration of sustainability principles and practices in its activities. However, the green label will be only given to a service where at least one criterion of each sustainability dimension is compiled (according to similar approach of GRI application level (GRI, 2013b)). This requirement aims to avoid the award of the sustainability label to a service that accomplishes the needed percentile of indicators but which are related to only one or two sustainability dimensions.

Following the purpose stated by the ISO 14020 and ISO 14024 standards (ISO, 2000, 1999b), this label proposal constitutes a voluntary multi-criteria based approach to identify public services with sustainability practices and measures in their activities and strategies. It is intended to be a thirdpart programme in order to guarantee the process transparency.

A sustainability label for local public services should not have marketing purposes in public sector. This proposed scheme does not intend to highlight the best public service. Rather, it aims to award public services that accomplish the established criteria showing that they incorporate sustainability practices in their activities besides what could be mandatory in their regular duties.

The developed framework was applied to an exploratory case study (see following chapter) that was used as a flexible approach that can be tailored to different situations or conditions. The degree of required adaptation will be based upon characteristics of a given public service, context features and data limitations and drawbacks. Exploratory studies debate the value of future developments regarding different hypotheses or propositions (Yin, 2009).

\subsection{Exploratory case study}

To test the proposed approach a local public service of a Portuguese municipality was used as exploratory case. This case aims to be representative of public services conducted by local governments. An initial review of the public service was supported by a pre-designed checklist of questions, which includes the analysis of the aim, scope, mission and activities (inputs, processes, outputs and outcomes) and the characterisation of the sustainability policies and practices undertaken by the service. This initial survey shows the level of integration of organisation responses to sustainability issues (according to Fig. 1).

The sustainability label conceptual framework was applied to the licensing and support of economic activities service of the Portuguese municipality of Oeiras. The municipality of Oeiras belongs to the metropolitan area of Lisbon, representing almost $9 \%$ of its population (170000 inhabitants) (Gabinete do Desenvolvimento Municipal/CMO, 2009). This municipality was used as an exploratory case study due to its relevance in the metropolitan area of the Portuguese capital and because it stands out for its environmental and sustainability practices at local level, such as the Agenda 21 and the Covenant of Mayors.

The service of licensing and support to economic activities is available on the majority of the Portuguese municipalities. In the municipality of Oeiras it is supervised by the Division of Urban Management and Support to Economic Activities. Its main responsibilities cover the instruction and preparation of decisions related to requests for construction to prior notification and authorisation, licensing of economic activities, monitoring construction work and urban supervision (Diário da República, 2014). The Division has 34 employees. This public service has a great responsibility to the citizens due to its proximity to the local community and their economic activities but it has not implemented any kind of labels or certification's systems.

The definition of the activities and operations of the service, including inputs, processes, outputs and outcomes (as suggested by Carter et al., 1992) was a fundamental step to test the conceptual framework and assess the sustainability performance of the service (Fig. 2).

This service is conducted under the Portuguese Legal Framework of Urbanization and Construction and is currently in accordance with the national legislation and with the application fees set in the Regulation of Fees and Other Revenues of the city of Oeiras. The service has its geographical jurisdiction within the municipality of Oeiras, where users of the service correspond to any individual or economic institution wishing to start or modify an activity in this territory. To conduct its activity, this public service also develops partnerships with several public and private institutions, requesting technical advices and inspections. For example, a technical advice may be requested to the Portuguese National Tourist Agency for tourism accommodations construction, or to the Portuguese Social Security Agency for licensing of nursing facilities. Therefore, most inspections have to match with the respective institutional agreements.

The main activities of the service are the following (Diário da República, 2014):

- Licensing the operation of commercial business, tourism, catering and drinks, and equipment, as well as licenses related to noise levels of economic activities and to the occupation of public space due to street work. 


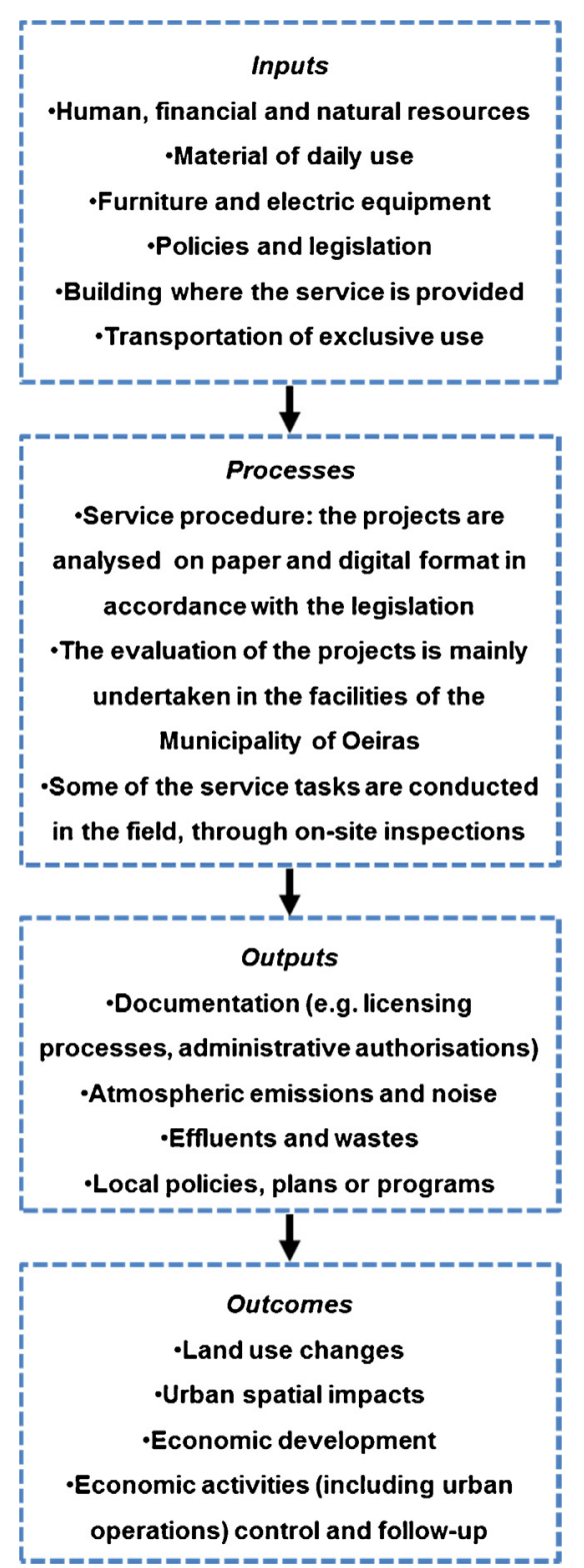

Fig. 2. Model of the operations and activities of the exploratory case study: the licensing and support of economic activities service of the municipality of Oeiras, Portugal.

- Updating census of commercial business, tourism, catering and drinks, and equipment.

- Promoting technical advice to individuals related to any procedure related to the service.

- Instructing and licencing or authorise processes related to telecommunication infrastructures, inspection of elevators, warehouses and fuel storage and recreation areas except when temporary.

Users can find information online, knowing in advance the necessary documents to present on licensing procedures, avoiding unnecessary travels.

For the sustainability assessment of this local public service, according to the framework presented earlier, documental and observed qualitative data was collected to assess the criteria and associated indicators. This data was complemented with semistructured interviews to selected members of the municipality staff, involved or in charge of the public service. The raw data obtained was mainly qualitative, due to the lack of established and formal monitoring processes in the service. These data collection was carried out in June 2014.

\section{Results and discussion}

\subsection{Application of the sustainability label framework}

The conceptual model was applied to the exploratory case study, through the developed criteria and indicators synthesised in Table 1. Fig. 3 shows the results for each of the thematic areas and their respective criteria/indicators status.

Overall, results indicate that the service fulfils only 10 out of 36 criteria. The service did not complied with 12 criteria and 2 were not applicable. These 2 criteria (EN14 and EN15) were not applicable because the building where this public service is provided does not have its own facilities to produce energy. Twelve (12) criteria could not be analysed due to the lack of available data. Therefore, this public service would be awarded with the orange sustainability label ( $28 \%$ of the criteria were fulfilled). The thematic area of Economic Aspects had the worst score within the three thematic areas considered by the proposed label. The economic dimension includes 5 criteria/indicators, covering Economic Development (3) and Financial Performance (2), but the assessed public service did not comply with any of them (see Fig. 3). The fact that 12 criteria could not be analysed clearly points to a first important finding of building a sustainability label: the awareness of the lack of data for decision making, for ensuring transparency and for communication to the public. In Portugal, as in other countries, as recognised by Ferrarini et al. (2001) and Nader et al. (2008), there is a lack of baseline data at local scales associated to the lack of resources, such as time, funding and/or manpower or to other governance factors. Furthermore, sustainability reporting is not required by law (Williams et al., 2011) and the voluntary nature of these assessments uncovers a weak implementation at the local level in the country (Moreno Pires and Fidélis, 2012).

Even though in this exploratory case study it was not possible to assess some of the criteria/indicators, it shows that this tool can be used to assess sustainability of public services according to the established criteria, and communicate the performance through a label. It is also shown that many of the criteria from services group of the EU ecolabel are applicable to a public service. As stated by Normann (2001) services have similar characteristics, different from goods. The use of some GRI indicators for public agencies also demonstrated that are applicable to this case, showing potential for further developments and uses. In addition to support direct sustainability communication to internal and external stakeholders, as highlighted by Dosi and Moretto (2001), when applying this label, the organisation can identify key-aspects to improve in the service sustainability performance in its different domains. For example, regarding water and effluents, the service has no procedures and tools to monitor the water flow debit, water consumption, the origin of the water used and potential related ecosystems affected. Also, there are no strategies and measures to increase water efficiency and reuse, or to purchase detergents and disinfectants with environmental certifications. To improve the organisational and service water performance, the municipality could follow other examples of good practice at local level such as the ones highlighted by Ivey et al. (2006), and implement a policy of efficient water consumption and integrate practices for the reuse of water in some places such as toilets or gardens. As stressed by Yuling (2009), local water management policies and practices are, and should be, interlinked with local government policies, in particular related with environmental protection measures. 


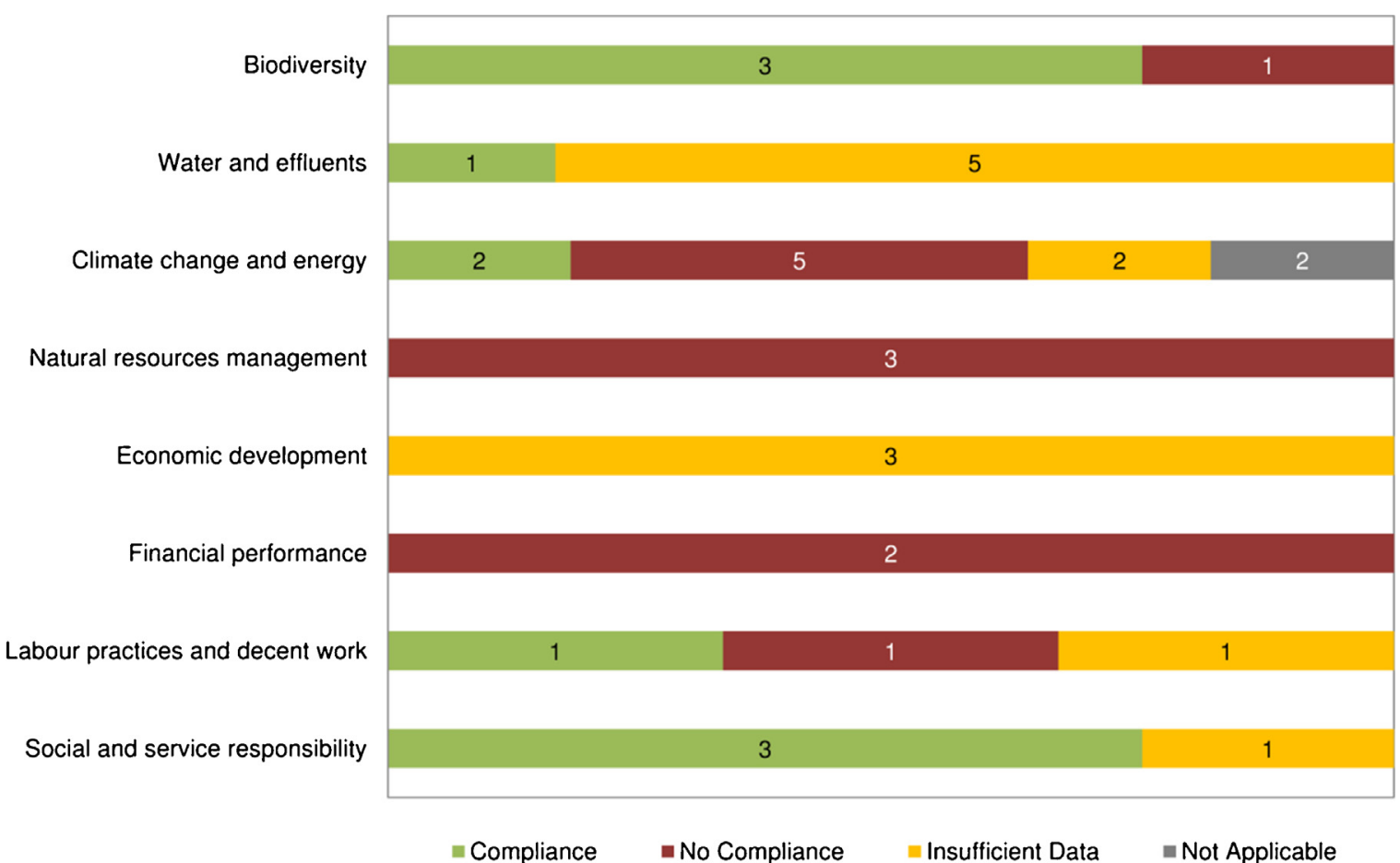

Fig. 3. Summary of criteria and indicators assessed in the licensing and support of economic activities service of the municipality of Oeiras, Portugal.

Regarding stakeholder communication, the initial survey (see Section 3.2) stressed that this service has to involve stakeholders to provide the service due to mandatory administrative procedures or when someone requires it. There are no information activities, except when necessary based on request of any stakeholder or on the advice of public and private entities during the procedure of activities and operations of a process. Any person interested in a specific process can consult it on the building where the service is provided and be attended daily by those responsible for the service. Communication with both internal (e.g. employees, managers) and external stakeholders (similar services, other public and private institutions service related, local community, public) is essential to not compromise the continuous improvement of the service performance. It is important to demonstrate that the organisational results take into account stakeholders concerns (Perrini and Tencati, 2006).

Despite the implementation of relevant formal and informal practices in this exploratory case study, like the commitment to the goals of the Covenant of Mayors, more good local practices could be incorporated in the service based on these criteria. By implementing these criteria and indicators to monitor and assess the sustainability performance, the public service could have the willingness to take the lead and develop a sustainability strategy for the whole public organisation. The sustainability label could be a complement to the sustainability reports used to communicate to stakeholders the results of the sustainability strategy of organisations (Farneti and Guthrie, 2009). It could set essential tasks to implement practices and tools as well as to conduct information campaigns to engage organisational stakeholders.

\subsection{Lessons learned}

Public organisations sustainability cannot be recognised only within the confines of traditional environmental services, like for example waste management. The administration needs modification to take into account sustainability management and performance in a more holistic way. Otherwise, the responsibility of local authorities to achieve performance encompassing all dimensions of sustainability will be mainly insignificant (Enticott and Walker, 2008).

The integration of environmental, economic and social concerns in the public sector breaks the stigma of this sector to achieve only what is mandatory. The adoption of voluntary instruments is an important sign of the government commitment to sustainable development on the State's organisations. As highlighted by Petrosillo et al. (2012), the effectiveness and extension of voluntary procedures in local authorities represents a relevant step forward in the field of pro-active management approach.

As a communicative tool, the proposed sustainability label informs stakeholders about the sustainability performance of the public services provided by the organisation. As stated by Nielsen and Thomsen (2011), local governments benefit with partnerships or networks to become ambassadors and change agents. Thus using a sustainability label for public services would potentiate organisation's commitment to sustainable development, creating specific outcomes.

Although the works of van Loo et al. (2014) and Vecchio and Annunziata (2015) are also focused on labels, only few key-indicators are encompassed, mainly from the environmental dimension. On one hand this can facilitate label recognition by stakeholders, satisfying one of its main goals as a communication tool. On the other hand, it does not allow an integrated assessment of the impacts of a specific product or an organisation.

A sustainability assessment and communication tool such as the sustainability label proposed in this work can be useful to assess and disclose the impacts at local level due to the closeness of this service objectives and activities to users. This label aims to stand out proactive services in the public organisations. Also, this label proposal, by integrating and complementing in an innovative way, well-known and established tools (EU ecolabel and GRI indicator and criteria), could benefit from their current recognition and acceptance. Also it is a first attempt to link performance assessment and communication in public services, using a label for communication purposes in order to offering the sustainability performance assessment results 
at the same time that the service is delivered. As stated by Scipioni et al. (2009), sustainable development needs the knowledge of the local economic opportunities, local environmental conditions, and social characteristics. Local public services need to understand and assess the potential environmental, economic and social impacts of certain activities before a decision is made and before the service is provided to the community.

There is a need to adjust some of the proposed criteria and performance indicators in order to make some of them more easily evaluated, and even more tailored to the local administration context, considering that the lack of baseline data is a frequent reality at local level. In addition, a voluntary monitoring system could be also added to the formal monitoring and data evaluation procedures, where the raw data for the indicators would be collected/evaluated by the local service stakeholders (for example employees could evaluate the services performance for water and energy efficiency measures or users satisfaction). According to Reed (2008) stakeholder involvement increases the quality of the environmental decisions because information inputs taken into account are more comprehensive. According to Measham and Barnett (2007), several government programmes in Australia, UK, Canada and USA rely heavily on volunteers. For instance, in the USA there are different programmes to assess water quality in estuaries (Ohrel and Register, 2006), lakes (USEPA, 1997) and wetlands (USEPA, 2000). As stressed by Ramos et al. (2014), stakeholders can be part of the staff that supports sustainability assessment and reporting.

Very often, municipalities adopt different organisational sustainability performance indicators to assess similar management aspects (Mazzi et al., 2012). Consequently, it is a complex task to compare sustainability performance of the different municipalities. Standard tools adapted to local authorities will contribute to compare sustainability performances from different organisations (Emilsson and Hjelm, 2005). The use of a sustainability label for local public services, in particular applying it to different municipalities, could be an important step to comparing the sustainability performance of services, and to some extent the organisational performance, through the use of common criteria and indicators. Thus, an integrated approach for public services performance assessment, such as the use of sustainability indicators guarantee the assessment of sustainability performance aspects in the public sector, assuring the adoption of sustainable practices.

The activities and operations of public services are generally based on the national laws, where most of the key factors of sustainability are not considered. If central governments start to encourage and reward the use of labels, sustainable performance assessments of public services could be put into practice and it would be possible to compare and improve them. In the long term, organisations with sustainable certifications can obtain positive impacts and improvements in the entire organisational performance. At the same time they will encourage other organisations to accomplish the same criteria. Beside this, they could benefit from the level of productivity and service quality, increasing public satisfaction by the communication of their performance to users. It is necessary that the service users are informed to understand and trust the information on the label, being only effective if the label is already known by the users (Sammer and Wüstenhagen, 2006). Thus, education and training initiatives could be an important driver in order to increase the level of sustainability label knowledge in stakeholders understanding. As stated by Hansmann et al. (2006) it is important to know public expectations and increase the label knowledge and public awareness. According to Freeman (1984), stakeholders need to be involved into the organisation such as the mutual interests can be accomplished because they have the capacity to influence the organisation and other stakeholders. Decisions may affect a variety of stakeholders and they influence the achievement of organisational plans (Waligo et al., 2014).

\section{Conclusions}

The public sector has been increasingly questioned about its services usefulness and effectiveness and its sustainability performance and related environmental, economic and social impacts. Hence, this sector has to justify its existence, increasing the productivity, competitiveness and user's satisfaction. Public services need to create an intrinsic value that could support the state to stand out as a sustainable service provider. Public agencies could play a central role to national and global progress towards sustainable development. Also, they have a civic responsibility to properly manage public goods, resources, and/or facilities. The wide range of public services, in particular at local level, shows that they are crucial on the direct and indirect influence of other agents on the market, mainly because they interact with all economic activities and stakeholders. Therefore, the use of a sustainability label for local public services can allow to assess its performance and to communicate to stakeholders in a transparent and comparable way. Besides, a sustainability label for local public services could contribute for the achievement of local, national, European or international targets on tackling namely environmental global problems, like for example climate change.

This research developed a conceptual framework based on a set of criteria and indicators to support the adoption of a sustainability label to assess and communicate the sustainability of local public services. Those criteria and indicators were adapted from the well-known standardised tools, EU ecolabel and GRI guidelines, and applied to an exploratory case study of a Portuguese local public service. Although those two tools have different aims and targets they are both based on criteria/indicators of performance assessment and have the same purpose of communication to stakeholders. Also they complement each other since EU ecolabel mainly focus the environmental dimension of sustainability, and the GRI is sustainability oriented. The case study of the licensing and support of economic activities service of the municipality of Oeiras showed how potentially useful could be this kind of tool. Also, the test provided evidences that the identified performance sustainability profile is similar to other public services contexts in southern European countries, namely regarding the lack of data and a general poor to fair sustainability performance. From the 36 criteria and indicators used, this service only complied with 10 . This lack of accomplishment can be justified by several factors, including the inexistence of an organisational monitoring system and the dearth of awareness on sustainability practices in the organisation, even considering that this service is integrated in a well-known large municipality with several commitments to sustainability already in place. Several steps need to be taken in this type of local public services to start implementing organisational sustainability practices and performance monitoring schemes in their activities.

Overall, the proposed label provides an important tool with potential to communicate local public services' sustainability to stakeholders. It could also provide an early warning to organisations at local level that have not yet integrated sustainable practices in their operational and strategic activities. Nevertheless, there is the need to adapt and improve the proposed criteria and indicators, namely searching ways to turn them more easily assessed, and test with other local public services. For other testing, improvements and validation the proposed conceptual tool, should be applied in other services of the municipality of Oeiras, other municipalities in Portugal or other countries.

This research constitutes a first approach to highlight the importance of assessing and communicating sustainability performance 
of public services. There is still a need to encompassing how the proposed sustainability label scheme could be implemented and who would be responsible for the process. A third-part certification entity would be important to validate this tool.

Public services are the central outcome of public organisations and the sustainability performance of these services reflects the commitment of the organisation to sustainable development. This could contribute to support performance assessments and benchmarking of public services grounded on a comprehensive set of criteria and indicators.

\section{Acknowledgments}

The authors would like to express their gratitude for the constructive comments provided by the anonymous reviewers. The authors gratefully acknowledge support by the Fundação para a Ciência e a Tecnologia through the project PTDC/AAC$\mathrm{AMB} / 119508 / 2010$. CENSE is financed through Strategic Project Pest-OE/AMB/UI4085/2013 from Fundação para a Ciência e Tecnologia, Portugal.

\section{References}

Adams, C., Muir, S., Hoque, Z., 2014. Measurement of sustainability performance in the public sector. Sustain. Account. Manag. Policy J. 5, 46-67.

van Amstel, M., Driessen, P., Glasbergen, P., 2008. Eco-labeling and information asymmetry: a comparison of five eco-labels in The Netherlands. J. Clean. Prod. $16,263-276$.

Ball, A., Bebbington, J., 2008. Accounting and reporting for sustainable development in public service organizations. Public Money Manag., 37-41.

Ball, A., Grubnic, S., 2007. Sustainability accounting and accountability in the public sector. In: Unerman, J., Bebbington, J., O’Dwyer, B. (Eds.), Sustainability Accounting and Accountability. Routledge, Oxon, pp. 243-265.

Bebbington, J., Higgins, C., Frame, B., 2009. Initiating sustainable development reporting: evidence from New Zealand. Account. Audit. Account. J. 22, 588-625.

Big Room, 2014. Ecolabel index, Retrieved from: www.ecolabelindex.com (February 2014).

Boland, T., Fowler, A., 2000. A systems perspective of performance management in public sector organisations. Int. J. Public Sect. Manag. 13, 417-446.

Bornmann, L., Leydesdorff, L., Mutz, R., 2013. The use of percentiles and percentile rank classes in the analysis of bibliometric data: opportunities and limits. J. Informetr. 7, 158-165.

Brammer, S., Walker, H., 2011. Sustainable procurement in the public sector: an international comparative study. Int. J. Oper. Prod. Manag. 31, 452-476.

Bratt, C., Hallstedt, S., Robèrt, K.H., Broman, G., Oldmark, J., 2011. Assessment of eco-labelling criteria development from a strategic sustainability perspective. J Clean. Prod. 19, 1631-1638.

Caeiro, S., Ramos, T.B., Huisingh, D., 2012. Procedures and criteria to develop and evaluate household sustainable consumption indicators. J. Clean. Prod. 27, $72-91$.

Carter, F., Klein, R., Day, P., 1992. How Organizations Measure Sucess: The Use of Performance Indicators in Government. Routledge, London and New York.

CEEP, 2009. Best CSR Practices in Public Services, Brussels, Belgium.

Comyns, B., Figge, F., Hahn, T., Barkemeyer, R., 2013. Sustainability reporting: the role of "Search" "Experience" and "Credence" information. Account. Forum 37, 231-243.

DEFRA, 2007. Securing the Future: UK Government Sustainable Procurement Action Plan Incorporating the Government response to the Report of the Sustainable Procurement Task Force, London.

Diário da República, 2014. Regulamento orgânico dos serviços do Município de Oeiras (Organic Regulation of the services of the municipality of Oeiras), Despacho n. 5021/2014.

Donnelly, A., Jones, M., O’Mahony, T., Byrne, G., 2007. Selecting environmental indicator for use in strategic environmental assessment. Environ. Impact Assess. Rev. 27, 161-175.

Dosi, C., Moretto, M., 2001. Is ecolabelling a reliable environmental policy measure? Environ. Resour. Econ. 18, 113-127.

EC, 2009a. 2009/578/EC: Commission Decision of 9 July 2009 establishing the ecological criteria for the award of the Community eco-label for tourist accommodation service (notified under document number C(2009) 5619) (Text with EEA relevance)

EC, 2009b. EC 2009/564/EC: Commission Decision of 9 July 2009 establishing the ecological criteria for the award of the Community eco-label for campsite service (notified under document number C(2009) 5618) (Text with EEA relevance).

EC, 2010. Regulation (EC) No. 66/2010 of the European Parliament and of the Council of 25 November 2009 on the Eu Ecolabel.

EC, 2014. Product Groups and Criteria, Retrieved from: http://ec.europa.eu/ environment/ecolabel/products-groups-and-criteria.html (February 2014).
Emilsson, S., Hjelm, O., 2005. Development of the use of standardized environmental management systems (EMSs) in local authorities. Corp. Soc. Responsib. Environ. Manag. 12, 144-156.

Enticott, G., Walker, R.M., 2008. Sustainability, performance and organizational strategy: an empirical analysis of public organizations. Bus. Strateg. Environ. $17,79-92$.

USEPA, 1997. Volunteer Lake Monitoring: A Methods Manual. EPA 440-4-91-002. U.S. Environmental Protection Agency, Office of Water, Office of Wetlands, Oceans, and Watersheds, Wetlands Division, Washington, DC.

USEPA, 2000. Volunteer Wetland Monitoring: An Introduction and Resource Guide. EPA 843-B-00B0001. U.S. Environmental Protection Agency, Office of Wetlands, Oceans, and Watersheds, Wetlands Division, Washington, DC.

Farneti, F., Guthrie, J., 2009. Sustainability reporting by australian public sector organisations: why they report. Account. Forum 33, 89-98.

Farneti, F., Guthrie, J., Siboni, B., 2011. Social and sustainability reporting in Italian local governments: what is not reported? In: Social Accounting and Public Management Accountability for the Common Good, Routledge.

Ferrarini, A., Bodini, A., Becchi, M., 2001. Environmental quality and sustainability in the province of Reggio Emilia (Italy): using multi-criteria analysis to assess and compare municipal performance. J. Environ. Manag. 63, 117-131.

Freeman, R.E., 1984. Strategic Management: Stakeholder Approach. Pitman, Boston, MA.

Gabinete do Desenvolvimento Municipal/CMO, 2009. Oeiras, Factos e Números (Oeiras, Facts and Numbers).

GRI, 2005. GRI Sector Supplement for Public Agencies Pilot Version 1.0. Global Reporting Initiative.

GRI, 2013a. G4 Sustainability Reporting Guidelines. Implementation Manual. Global Reporting Initiative.

GRI, 2013b. GRI Application Level Check Methodology. Global Reporting Initiative.

Guthrie, J., Farneti, F., 2008. GRI Sustainability reporting by australian public sector organizations. Public Money Manag. 28, 361-366.

Hansmann, R., Koellner, T., Scholz, R.W., 2006. Influence of consumers' socioecological and economic orientations on preferences for wood products with sustainability labels. For. Policy Econ. 8, 239-250.

Hartlieb, S., Jones, B., 2009. Humanising business through ethical labelling: progress and paradoxes in the UK. J. Bus. Ethics 88, 583-600.

Holden, M., 2006. Revisiting the local impact of community indicators projects: sustainable Seatle as prophet in its own land. Appl. Res. Qual., 253-277.

Hoppe, T., Coenen, F., 2011. Creating an analytical framework for local sustainability performance: a Dutch case study. Local Environ. 16, 229-250.

Ibanez, L., Grolleau, G., 2008. Can ecolabeling schemes preserve the environment? Environ. Resour. Econ. 40, 233-249.

ICLEI European Secretariat, Ambiente Italia, Lake Constance Foundation, 2012. Background Report for the Development of the Reference Document on Best Environmental Management Practice in the Public Administration Sector.

ISO, 1999a. ISO 14021 - Environmental Labels and Declarations - Self-declared Environmental Claims - Type II Environmental Labelling. International Organization for Standardization, Geneva.

ISO, 1999b. ISO 14024 - Environmental Labels and Declarations - Type I Environmental Labelling - Principles and Procedures. International Organization for Standardization, Geneva.

ISO, 2000. ISO 14020 - Environmental Labels and Declarations - General Principles. International Organization for Standardization, Geneva.

ISO, 2006. ISO 14025 - Environmental Labels and Declarations - Type III Environmental Declarations - Principles and Procedures. International Organization for Standardization, Geneva.

Ivey, J.L., Loë, R., De Kreutzwiser, R., Ferreyra, C., 2006. An institutional perspective on local capacity for source water protection. Geoforum 37, 944-957.

Jarrar, Y., Schiuma, G., 2007. Measuring performance in the public sector: challenges and trends. Meas. Bus. Excell. 11, 4-8.

Lamprinidi, S., Kubo, N., 2010. Debate: the global reporting initiative and public agencies. Public Money Manag., 37-41.

Larsen, H.N., Hertwich, E.G., 2011. Analyzing the carbon footprint from public services provided by counties. J. Clean. Prod. 19, 1975-1981.

Lavallée, S., Plouffe, S., 2004. The ecolabel and sustainable development. Int. J. LifeCycle Assess. 9, 349-354.

Li, F., Liu, X., Hu, D., Wang, R., Yang, W., Li, D., Zhao, D., 2009. Measurement indicators and an evaluation approach for assessing urban sustainable development: a case study for China's Jining City. Landsc. Urban Plan. 90, 134-142.

Lozano, R., Huisingh, D., 2011. Inter-linking issues and dimensions in sustainability reporting. J. Clean. Prod. 19, 99-107.

Lundberg, K., Balfors, B., Folkeson, L., 2009. Framework for environmental performance measurement in a Swedish public sector organization. J. Clean. Prod. 17, 1017-1024.

Mascarenhas, A., Coelho, P., Subtil, E., Ramos, T.B., 2010. The role of common local indicators in regional sustainability assessment. Ecol. Indic. 10, 646-656.

Mazzi, A., Mason, C., Mason, M., Scipioni, A., 2012. Is it possible to compare environmental performance indicators reported by public administrations? Results from an Italian survey. Ecol. Indic. 23, 653-659.

McMahon, S.K., 2002. The development of quality of life indicators - a case study from the city of Bristol, UK. Ecol. Indic. 2, 177-185.

Measham, T.G., Barnett, G.B., 2007. Environmental Volunteering: Motivations, Modes and Outcomes, Socio-Economics Environ. Discuss. CSIRO Work. Pap. Ser 2007-03. 
Mendes, P., Santos, A.C., Perna, F., Ribau Teixeira, M., 2012. The balanced scorecard as an integrated model applied to the Portuguese public service: a case study in the waste sector. J. Clean. Prod. 24, 20-29.

Michelsen, O., Boer, L., 2009. Green procurement in Norway; a survey of practices at the municipal and conty level. Environ. Manage. 91, 160-167.

Montesinos, V., Brusca, I., 2009. Towards performance, quality and environmental management in local government: the case of Spain. Local Gov. Stud. 35, 197-212.

Moreno Pires, S., 2014. Indicators of sustainability. In: Michalos, A.C. (Ed.), Encyclopedia of Quality of Life and Well-Being Research. Springe, Dordrecht, Netherlands, pp. 3209-3214.

Moreno Pires, S., Fidélis, T., 2012. A proposal to explore the role of sustainability indicators in local governance contexts: the case of Palmela, Portugal. Ecol. Indic. 23, 608-615.

Moreno Pires, S., Fidélis, T., Ramos, T.B., 2014. Measuring and comparing local sustainable development through common indicators: constraints and achievements in practice. Cities, 1-9.

Mori, K., Christodoulou, A., 2012. Review of sustainability indices and indicators: towards a new city sustainability index (CSI). Environ. Impact Assess. Rev. 32, 94-106.

Nader, M.R., Salloum, B.A., Karam, N., 2008. Environment and sustainable development indicators in Lebanon: a practical municipal level approach. Ecol. Indic. 8, $771-777$.

Navarro Galera, A., de los Ríos Berjillos, A., Ruiz Lozano, M., Tirado Valencia, P., 2014. Transparency of sustainability information in local governments: Englishspeaking and Nordic cross-country analysis. J. Clean. Prod. 64, 495-504.

New Zealand Wine, 2014. Sustainable Winegrowing New Zealand, Retrieved from: http://www.nzwine.com/sustainability/sustainable-winegrowing-newzealand/ (February 2015).

Nielsen, A.E., Thomsen, C., 2011. Sustainable development: the role of network communication. Corp. Soc. Responsib. Environ. Manag. 18, 1-10.

Niemeijer, D., Groot, R.S., 2008. A conceptual framework for selecting environmental indicator sets. Ecol. Indic. 8, 14-25.

Nogueiro, L., Ramos, T.B., 2009. Environmental management practices in local public administration in Portugal. In: Mumba, A., Ketola, T. (Eds.), Responsible Leadership. Vaasan yliopisto, Vaasa, Finland, pp. 500-521.

Nogueiro, L., Ramos, T.B., 2014. The integration of environmental practices and tools in the Portuguese local public administration. J. Clean. Prod. 76, 20-31.

Norén, H., Malmborg, F.von, 2004. Are standardized EMSs useful in local authorities? A study of how a tool from the private sector is used in the public sector. Bus. Strateg. Environ. 13, 187-197.

Normann, R., 2001. Service Management: Strategy and Leadership in Service Businesses, 3 rd ed.

Ohrel, R., Register, K., 2006. Volunteer Estuary Monitoring: A Methods Manual, second ed. Office of Wetlands, Oceans and Watersheds to The Ocean Conservancy, USEPA, Washington, DC

Perrini, F., Tencati, A., 2006. Sustainability and stakeholder management: the need for new corporate performance evaluation and reporting systems. Bus. Strateg. Environ. 308, 296-308.

Petrosillo, I., De Marco, A., Botta, S., Comoglio, C., 2012. EMAS in local authorities: suitable indicators in adopting environmental management systems. Ecol. Indic. $13,263-274$

Ramos, T.B., Alves, I., Subtil, R., de Melo, J.J., 2007. Environmental pressures and impacts of public sector organisations: the case of the Portuguese military. Prog. Ind. Ecol. 4, 363-381.
Ramos, T.B., Caeiro, S., 2010. Meta-performance evaluation of sustainability indicators. Ecol. Indic. 10, 157-166.

Ramos, T.B., Martins, I.P., Martinho, A.P., Douglas, C.H., Painho, M., Caeiro, S., 2014. An open participatory conceptual framework to support State of the Environment and Sustainability Reports. J. Clean. Prod. 64, 158-172.

Reed, M.S., 2008. Stakeholder participation for environmental management: a literature review. Biol. Conserv. 141, 2417-2431.

Saha, D., 2009. Empirical research on local government sustainability efforts in the USA: gaps in the current literature. Local Environ. 14, 17-30.

Sammer, K., Wüstenhagen, R., 2006. The influence of eco-labelling on consumer behaviour - results of a discrete choice analysis for washing machines. Bus. Strateg. Environ. 199, 185-199.

Santos, R., Antunes, P., Baptista, G., Mateus, P., Madruga, L., 2006. Stakeholder par ticipation in the design of environmental policy mixes. Ecol. Econ., 100-110.

Scipioni, A., Mazzi, A., Mason, M., Manzardo, A., 2009. The dashboard of sustainability to measure the local urban sustainable development: the case study of Padua municipality. Ecol. Indic. 9, 364-380.

Steinemann, A., 2003. Drought indicators and triggers: a stochastic approach to evaluation. J. Am. Water Resour. Assoc. 39 (5), 1217-1233.

Strengers, Y., 2004. Environmental culture change in local government: a practised perspective from the International Council for Local Environmental Initiatives-Australia/New Zealand. Local Environ. 9, 621-628.

Tanguay, G.A., Rajaonson, J., Lefebvre, J.-F., Lanoie, P., 2010. Measuring the sus tainability of cities: an analysis of the use of local indicators. Ecol. Indic. 10 407-418.

Thøgersen, J., 2002. Promoting “green” consumer behavior with eco-labels. In: Dietz T., Stern, P.C. (Eds.), New Tools for Environmental Protection. National Academy Press, Washington, DC, pp. 83-104.

UNOPS, 2009. A Guide to Environmental Labels - For Procurement Practitioners of the United Nations System. UNEP, Sustainable United Nations.

USEPA, 1999. Profile of Local Government Operations. EPA 310-R-99e001. U.S. Environmental Protection Agency, Office of Enforcement and Compliance Assurance, Washington, DC.

van Loo, E.J., Caputo, V., Nayga Jr., R.M., Verbeke, W., 2014. Consumers' valuation of sustainability labels on meat. Food Policy 49, 137-150.

Vecchio, R., Annunziata, A., 2015. Willingness-to-pay for sustainability-labelled chocolate: an experimental auction approach. J. Clean. Prod. 86, 335-342.

Waas, T., Hugé, J., Block, T., Wright, T., Benitez-Capistros, F., Verbruggen, A., 2014 Sustainability assessment and indicators: tools in a decision-making strategy for sustainable development. Sustainability 6, 5512-5534

Waligo, V.M., Clarke, J., Hawkins, R., 2014. The “leadership-stakeholder involvemen capacity" nexus in stakeholder management. J. Bus. Res. 67, 1342-1352.

Walker, H., Brammer, S., 2012. The relationship between sustainable procurement and e-procurement in the public sector. Int. J. Prod. Econ. 140, 256-268.

Welford, R., Young, W., Ytterhus, B., 1998. Towards sustainable production and consumption: a literature review and conceptual framework for the service sector. Eco-Manag. Audit. 5, 38-56.

Williams, B., Wilmshurst, T., Clift, R., 2011. Sustainability reporting by local government in Australia: current and future prospects. Account. Forum 35, 176-186.

Yin, R.K., 2009. Case Study Research: Design and Methods, fourth ed. SAGE Publications, Inc.

Yuling, S., 2009. The social and environmental costs associated with water management practices in state environmental protection projects in Xinjiang, China. Environ. Sci. Policy 12, 970-980. 